\title{
BIOLOGICAL ACTIVITIES AND CORRELATIONS TENDENCY OF ELECTROCHEMICAL PROPERTIES OF SOME INDOLIZINO[1,2-B]QUINOLINE DERIVATIVES
}

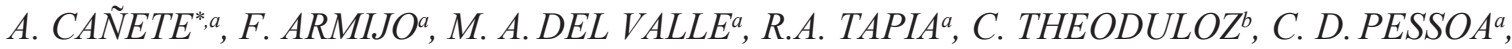 \\ L. CANTUARIAS ${ }^{a}$, G. RECABARREN ${ }^{a}$
}

${ }^{a}$ Facultad de Química, Pontificia Universidad Católica de Chile; ${ }^{b}$ Facultad de Ciencias de la Salud,

Universidad de Talca, Talca, Chile.

(Received: August 1, 2011 - Accepted: March 26, 2012)

\begin{abstract}
We report the preparation of a series of indolylquinone and pyridine derivatives in order to evaluate structure-activity relationships in human gastric (AGS), lung (SK-MES-1), bladder (J82) cancer cell lines and human normal lung fibroblasts (MCR-5). Two correlations tendency between half-wave redox potentials against their antineoplasic activity were found making it possible to establish that for epithelial human gastric cancer (AGS) cell lines and human normal lung fibroblasts (MCR-5). The quinone bioreduction should correspond to a one electron process under normomix conditions, whilst for all other lines this process should correspond to a two electron attachment via a hypoxic process.
\end{abstract}

Key Words: Quinone, Electrochemical properties, Antiproliferative activity.

\section{INTRODUCTION}

Quinones are molecules that occur in some natural and synthetic compounds; they are an important class of biological active agents which can be found in coenzyme $\mathrm{Q}$, vitamin $\mathrm{K}$ or in anticancer antibiotics like doxorubicin. ${ }^{1}$ Their mechanisms of action principally are dependent of their chemical structure. In this way, they can act as covalent modifiers of biomolecules such as DNA intercalators and/or as generators of reactive oxygen species through redox-cycling. ${ }^{2,3}$ Respect to reduction of quinones by enzymes, it would involves at least two kind of processes: one through an one electron pathway to produce semiquinone radicals by reductive enzymes like CYP450 reductase, cytochrome $\mathrm{b}_{5}$ reductase and ubiquinone oxireductase or by a two electron pathway to produce hydroquinones by reductive enzymes like DT-diaphorase. ${ }^{4}$ Inside of quinone family compounds, Indolizino[1,2-b]quinoline derivatives have a similar structure to Camptothecin derivatives, but only bearing four rings. ${ }^{6,7}$ In relationship of this molecules, it is known that molecules containing planar polycyclic aromatic rings and a conjugated quinone such as our derivatives tend to be the DNA-intercalating TOP inhibitors, which is in accordance with Moore's and Pindur's theory. ${ }^{8}$ Furthermore, SAR (structure activity relationships) studies obtained using indolequinone models for several quinone systems have showed that their pharmacokinetic properties are due the presence or absence of groups in positions 2, 3 and 5. It is worth to note that an aziridinyl group at position 5 plays an important role on the design and the selectivity and potency of anticancer prodrugs. ${ }^{9}$ On the other hand, the presence of electrowithdrawing groups in position-3 and/or heteroatoms in position-2 are other important factor to be considered in the design of selective anticancer drugs (see Figure 1).<smiles>[X]c1cccc2c1C(=O)C(Cl)=C(Cl)C2=O</smiles>

$\mathrm{X}: \mathrm{CH}$ or $\mathrm{N}$<smiles>[R]CC(C)=O</smiles>

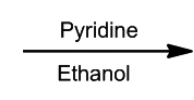

$$
\text { R: }
$$

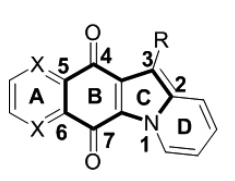

R: $\mathrm{CO}_{2} \mathrm{Et}, \mathrm{COCH}_{3}, \mathrm{CN}, \mathrm{CO}_{2} \mathrm{H}$
Figure 1 Synthesis of Indolizino[1,2-b]quinolin derivatives.

In order to study which are the effects produced by some electrowithdrawing groups at position- 3 and the presence of a nitrogen atom in the $\mathbf{A}$ ring, the aim of this work was to investigate if there are relationships between their biological activities and their electrochemical properties, to determinate if these compounds were able to be bioreduced to a semiquinone compound via one electron pathway under normoxic conditions or by means of a two electron reduction under hypoxic conditions to yield hydroquinones (diol).

\section{RESULT AND DISCUSSION}

Indolizino[1,2-b]quinoline derivatives, were prepared by Luckenbaugh et $a l .{ }^{5}$ in a one-pot reaction by condensation of 2,3-dichloro-1,4-naphthoquinone and an active $\beta$-carbonilic compounds in presence of a high excess of pyridine and ethanol. However, the reaction yields showed high variability depending on $\beta$-carbonilic compounds, ranging from $15 \%$ for quinone 3 to $91 \%$ for quinone 1. In order to improve these yields, we performed similar conditions but under microwave radiation yielding unsuccessful results (Table I).

All these compounds were studied against antineoplasic activity. Table II shows selected molecules tested on three human cancers types, corresponding to epithelial gastric (AGS), lung (SK-MES-1), and bladder (J82) cell lines. Also these molecules were tested in human normal lung fibroblasts (MCR-5). As a complementary work, we carried out electrochemical studies on these molecules looking for correlations between their obtained redox potentials and their displayed biological activities (Table II).

$\mathrm{IC}_{50}$ (Inhibit Cellular Proliferation by $50 \%$ ) values for the studied substrates, showed dependence upon structure modifications, such as the presence of different chemical groups in the $\mathbf{C}$ ring or the existence of a nitrogen atom in the $\mathbf{A}$ ring. The presence of electrowithdrawing groups in the $\mathbf{C}$ ring, shed light on about what kind of cytotoxic processes were taking place under hypoxic or normoxic conditions. When compounds 1, 4, 6 and 8 were compared (all of them lacking a nitrogen atom in the A ring), we found that the selectivity towards cancer cell lines was indifferent to structure modifications. In relation to functional groups, namely acetyl-, ester- and carboxylic acid groups, the results showed irrelevant differentiation regards to the $\mathrm{IC}_{50}$ values. However, nitrile derivatives showed positive activity in all cell lines including human normal lung fibroblasts (MCR-5). The activity displayed on these normomix cells might be due to the formation of N-hydroxyl amines intermediates in such aerobic conditions. On the other hand, carboxylic acid derivative $\mathbf{8}$ is practically selective only to AGS (gastric).

The biological activities for the quinone structures corresponding to compounds $\mathbf{2}, \mathbf{3}, \mathbf{5}$ and $\mathbf{7}$, demonstrated that these compounds have increased activity regarding to the naphthalene serie (compounds $\mathbf{1 , 4}$ and $\mathbf{6}$ ), displaying selectivity for SK-MES-1 (lung) and J82 (bladder) cell lines. This behavior is in agreement with the presence of aziridinyl groups at $\mathbf{A}$ ring, as was indicated by Xing et al..$^{9,10}$ noting that the presence of $\mathrm{N}$ atoms are important factors for the increased potency and selectivity of prodrugs. In the case of N,N-syn esther (2) was as active as Etoposide used as the reference molecule for all cell lines studied, contrasting with its $\mathrm{N}, \mathrm{N}-$ anti isomer (3), which displayed a high selectivity for SK-MES-1 (lung) and J82 (bladder) cell lines. Moreover, the anti isomer did not show any significant activity for AGS (gastric) and fibroblasts cell lines. Structures $\mathbf{5 ,} \mathbf{6}$ and $\mathbf{7}$ showed a moderated activity toward SK-MES-1 (lung) and J82 (bladder) cell lines. The influence of electrowithdrawing groups in the $\mathbf{C}$ ring was not relevant in all cases studied. The 
correlations tendency between the biological activity and the electrochemical evaluations through half-wave redox potentials of compounds 1-8 was carried out by cyclic voltammetry (in acetonitrile on platinum electrodes) yield interesting results. The electrochemical behavior was similar in all cases studied. The voltamograms showed only two consecutive reversible processes involving one electron, suitable for indolizino[1,2-b]quinoline derivatives in the conditions under which measurements were made. These systems showed reversible waves similar to those derived from 2-hydroxinaphthoquinones models described by Solorio-Alvarado et al. ${ }^{12}$ The correlation of the biological activity with half-wave potentials was made on the reversible waves b-c, reported as the stable formation of a dianion (Q-2).12 Data showed in Table II.

Table I. Synthesis yield data of indolozinquinolin-5,12-diones and indolozi naphthoquinolin-5,12-diones.

Compound

a Conventional heating $(24 \mathrm{~h})$

b. Microwave Irradiation (30min)
Table II. Cytotoxic activities and electrochemical properties of indolozinquinolin-5,12-diones and indolozinaphthoquinolin-5,12-diones.

\begin{tabular}{|c|c|c|c|c|c|c|}
\hline & & $\begin{array}{c}\mathbf{I C}_{50} \\
(\boldsymbol{\mu M})\end{array}$ & & & \\
\hline $\begin{array}{c}\text { Com- } \\
\text { pounds }\end{array}$ & $\begin{array}{c}\text { MRC-5 } \\
\text { Fibroblast }\end{array}$ & $\begin{array}{c}\text { SK- } \\
\text { MES-1 } \\
\text { lung }\end{array}$ & $\begin{array}{c}\text { J82 } \\
\text { Bladder }\end{array}$ & $\begin{array}{c}\text { AGS } \\
\text { Gastric }\end{array}$ & $\begin{array}{c}\mathbf{- E}_{1 / 2} \\
\left(\mathbf{1}^{\boldsymbol{a}}\right.\end{array}$ & $\begin{array}{c}-\boldsymbol{E}_{1 / 2} \\
(\mathbf{2})^{b}\end{array}$ \\
\hline 1 & $>100$ & 73 & 87.1 & $>100$ & 0,890 & 1,3303 \\
\hline 2 & 6.5 & 4.6 & 4.8 & 3.1 & 0,553 & 0,739 \\
\hline 3 & 96.9 & 1.8 & 2.1 & $>100$ & 0,810 & -- \\
\hline 4 & $>100$ & 68.1 & 70.1 & 90.9 & 0,821 & 1,292 \\
\hline 5 & $>100$ & 11.2 & 12.1 & $>100$ & 0,724 & 1,103 \\
\hline 6 & 53.9 & 24.6 & 20.3 & 25.8 & 0,772 & 1,345 \\
\hline 7 & 82.2 & 9.8 & 9.2 & 40.1 & 0,637 & -- \\
\hline 8 & 48.1 & $>100$ & $>100$ & 24.9 & 0.536 & 0,942 \\
\hline $\begin{array}{c}\text { Eto- } \\
\text { poside }\end{array}$ & 3.9 & 2.5 & 2.8 & 0.36 & & \\
\hline
\end{tabular}

a First redox half-wave potential, V vs SCE

b Second redox half-wave potential, V vs SCE

With these results at hand, it was possible to correlate the $\mathrm{IC}_{50}$ values for these compounds with their half-wave potentials, namely $\mathrm{E}_{12(1)}$ and $\mathrm{E}_{12(2)}$ in the different cell lines. The correlation of $\mathrm{E}_{1 / 2(1)}$ with IC50 obtained in human epithelial cells of gastric cancer (AGS) and human normal lung fibroblasts (MCR-5) had a similar trend according to Figure 2 (see trend $\mathbf{A}$ and $\mathbf{B}$ ). Also, the correlation displayed between $\mathrm{IC}_{50}$ and semi half-wave redox potential in lung (SK-MES-1) and bladder cancer cells (J82) follow a similar trend between them but different to $\mathbf{A}$ and $\mathbf{B}$ (see Figure 2 trend $\mathbf{C}$ and $\mathbf{D}$ ). This behavior allowed us to assign if the processes occur by normoxic or hypoxia conditions.

Taking into account that the biorreduction underwent by our tested quinone derivatives due to the presence of enzymes in MCR-5 cells was carried out under normoxic conditions and that this process occur as a one-electron reduction process, was possible to establish that for the AGS cell line, this process should correspond to electron pathway sensitive to oxygen. This result is consistent with the similar trends founded in the charts $\mathbf{A}$ and $\mathbf{B}$. For all other cell lines, (Figure 2, trends $\mathbf{C}$ and $\mathbf{D}$ ) this would indicate that these analogues generate their toxicity through a bioreduction process via two electrons, no sensitive to oxygen, according to a hypoxia process.
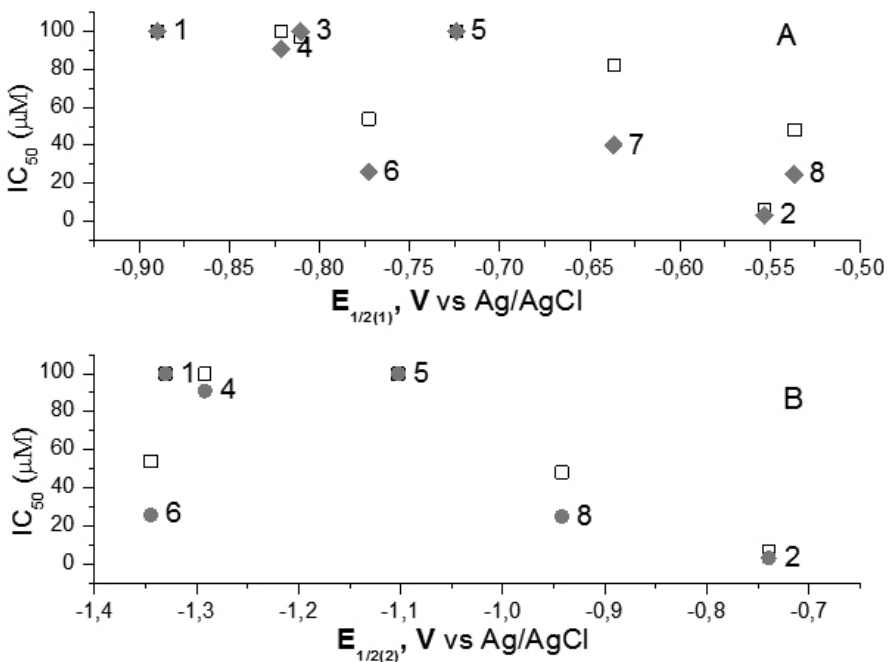

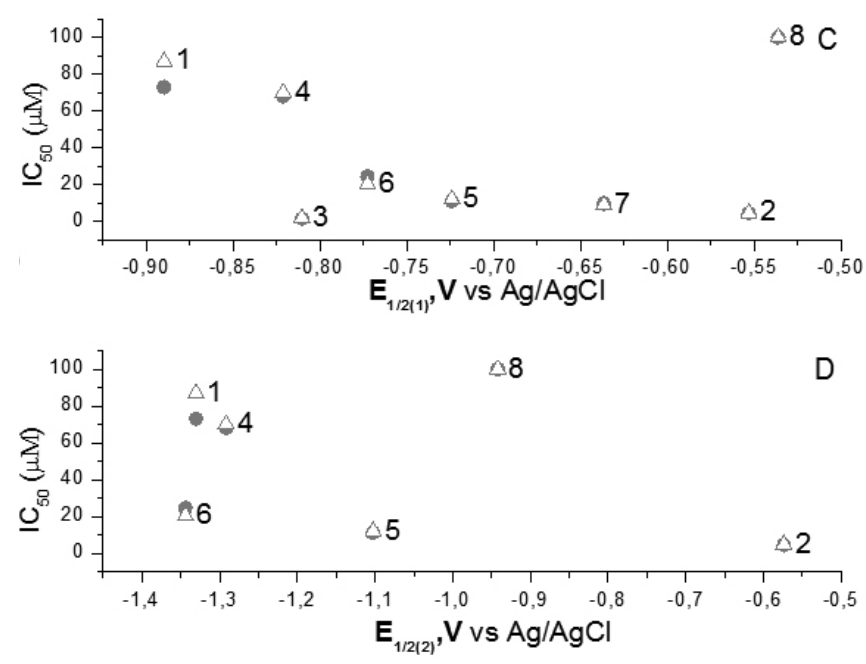

Figure 2, Correlation tendency between half-wave redox potentials and $\mathrm{IC}_{50}, \diamond$ Normal MRC-5, $\mathbf{a G S ,}$ OSK-MES-1, $\triangle \mathrm{J} 82$ cell lines.

As conclusion of our work it was possible to establish some structure activity relationships of indolizino [1,2-b] quinoline derivatives, emphasizing that the presence of a nitrogen atom in ring A plays an important role regarding the potency and selectivity on cancer cell lines. Also, it was possible to establish the mode of action of the substrates studied using tendency correlations between the half-wave redox potential and measured biological activities. Then, the combination of an indole ring analogue with a quinone must generate a largely conjugated system that may undergo electronic transfer processes, because these rings have a very rigid and coplanar conformation. Therefore, modification with different substituents at some position in the indole ring, or in the quinone system, must originate a new family of indolequinones which will differ in their electrodic processes, seeking to improve their redox mediating capacities. Specific studies on the interaction of analogues with DNA nucleic acids will be also accomplished.

\section{EXPERIMENTAL}

${ }^{1} \mathrm{H}$ and ${ }^{13} \mathrm{C}$ NMR spectra were obtained on AM-400 instruments, using tetramethylsilane as internal reference, using $\mathrm{CDCl} 3$ and DMSO-d solutions. EI-MS experiments were performed on a MAT 95XP Thermo-Finnigann spectrometer. The accurate mass measurements were performed at a resolution of $9000-10000$ (10\% valley definition) by voltage scanning using perfluorokerosene (PFK) as the reference compound. IR spectra (4000-250 $\mathrm{cm}-1$ ) were recorded with samples as $\mathrm{KBr}$ pellets on a Bruker Model Vector 22 spectrophotometer. Electrochemical measurements were performed on a $\mathrm{CHI}$ Instruments Model 900B potentiostat using a conventional three-electrode cell. Platinum and platinum wires were used as working and counter electrode, respectively. All potentials quoted in this work are refered to an $\mathrm{Ag} / \mathrm{AgCl}, \mathrm{KCl}$ (sat'd) reference electrode ( $0.197 \mathrm{~V}$ vs. NHE). Column chromatography was performed on silica gel Merck 60 (70-230 mesh). All reagents used were of analytical reagent grade from Sigma Chemical Co.(St Louis, MO, U.S.A) and melting points were determined on the Stuart Scientific SMP3 apparatus.

General procedures

The quinoline's compounds 1-7, were synthesized accord to reference [6], with exception of carboxylic acid compound.

To a $100 \mathrm{~mL}$ round bottom flask it was added $2.2 \mathrm{mmol}$ of 2,3-dichloronaphthalene-1,4-dione, $2.6 \mathrm{mmol}$ of aceto acetil derivative, 26 mmol of pyridine in $30 \mathrm{~mL}$ of ethanol. The suspension was reflux by 6 hours; the precipitated was filtered and was washed with water gently. The precipited formed was subsequently subjected to flash column chromatography packed manually with silica gel to give the corresponding target compound.

Ethyl 5,12-dioxo-5,12-dihydroindolizino[2,3-g]quinoline-6carboxylate (1): Orange solid, $\mathrm{mp} 227-228{ }^{\circ} \mathrm{C}$; IR $\left(\mathrm{KBr}, \mathrm{v}_{\mathrm{max}} \mathrm{cm}^{-1}\right)$ : 1678 , 1641, 1571, 1487, 1383. ${ }^{1} \mathrm{H}$ RMN $\left(\mathrm{CDCl}_{3}\right): 9.94(\mathrm{~d}, 1 \mathrm{H}, 4, \mathrm{~J}=7.00 \mathrm{~Hz}), 9.01$ $(\mathrm{dd}, 1 \mathrm{H}, 1, \mathrm{~J}=4.68,1.73 \mathrm{~Hz}), 8.54(\mathrm{dd}, 1 \mathrm{H}, \mathrm{J}=7.89,1.76 \mathrm{~Hz}), 8.35$ (dt, $1 \mathrm{H}, \mathrm{J}=$ 9.11, ), 7,63 (dd, 1H, J= 7.90, $4.70 \mathrm{~Hz}), 7,48(\mathrm{t}, 1 \mathrm{H}, \mathrm{J}=7.39 \mathrm{~Hz}), 7.23(\mathrm{t}, 1 \mathrm{H}$, $\mathrm{J}=7.68 \mathrm{~Hz}) 4.52\left(\mathrm{q}, 2 \mathrm{H}, \mathrm{CH}_{2} \mathrm{~J}=7,12 \mathrm{~Hz}\right), 1.49\left(\mathrm{t}, 3 \mathrm{H}, \mathrm{CH}_{3}, \mathrm{~J}=7,15 \mathrm{~Hz}\right) ;{ }^{13} \mathrm{C}$
NMR $\left(\mathrm{CDCl}_{3}\right): 14.3,61.1,106.35,116.0,121.1,122.9,126.9,128.1,128.6$, 130.9, 135.4, 139.9, 149.5, 154.1, 163.0, 173.1, 179.1. HRMS (EI) $\mathrm{m} / z$ calcd for $\mathrm{C}_{19} \mathrm{H}_{13} \mathrm{NO}_{4}: 319.08446$; found: 319.084335 .

Ethyl 6,11-dioxo-6,11-dihydrobenzo[f]pyrido[1,2-a]indole-12carboxylate (2): Orange solid, $\mathrm{mp} 158.9-159.3^{\circ} \mathrm{C}$; IR $\left(\mathrm{KBr}, \mathrm{v}_{\max } \mathrm{cm}^{-1}\right)$ : 1694 , 1673, 1473, 1250, 713. ${ }^{1} \mathrm{H} \mathrm{RMN}\left(\mathrm{CDCl}_{3}\right): 9.82(\mathrm{dt}, 1 \mathrm{H}, 4, \mathrm{~J}=6.97 \mathrm{~Hz}), 8.29$ (td, $1 \mathrm{H}, 1, \mathrm{~J}=9.11 \mathrm{~Hz}), 8.20(\mathrm{~m}, 2 \mathrm{H}, 7,10), 7,70(\mathrm{~m}, 2 \mathrm{H}, 8,9), 7,41$ (t, $1 \mathrm{H}, 2$, $\mathrm{J}=6.84 \mathrm{~Hz}), 7,16(\mathrm{t}, 1 \mathrm{H}, 3, \mathrm{~J}=6.96 \mathrm{~Hz}), 4.51\left(\mathrm{q}, 2 \mathrm{H}, \mathrm{CH}_{2} \mathrm{~J}=7,14 \mathrm{~Hz}\right), 1.50$ (t, $\left.3 \mathrm{H}, \mathrm{CH}_{3}, \mathrm{~J}=7,13 \mathrm{~Hz}\right) ;{ }^{13} \mathrm{C} \mathrm{NMR}\left(\mathrm{CDCl}_{3}\right): 14.3,61.0,106.0,117.3,120.9$, $122.4,125.9,127.2,127.7,128.2,128,6,133.1,133.4,133.7,134.1,139.5$, 163.2, 175.1, 180.1. HRMS (EI) $\mathrm{m} / z$ calcd for $\mathrm{C}_{18} \mathrm{H}_{12} \mathrm{~N}_{2} \mathrm{O}_{4}: 320.0797$; found: 320.079413 .

Ethyl

5,12-dioxo-5,12-dihydroindolizino[3,2-g]quinoline-11carboxylate (3): Orange solid, $\mathrm{mp} 232-233^{\circ} \mathrm{C}$; IR $1673\left(\mathrm{KBr}, \mathrm{v}_{\max } \mathrm{cm}^{-1}\right)$ : $1675,1637,1488,1383,1318 ;{ }^{1} \mathrm{H} \mathrm{RMN}\left(\mathrm{CDCl}_{3}\right): 9.08$ (dt, $1 \mathrm{H}, \mathrm{J}=7.00,1.11$ $\mathrm{Hz}), 9.00(\mathrm{dd}, 1 \mathrm{H}, \mathrm{J}=4.67,1.75 \mathrm{~Hz}), 8.56(\mathrm{dd}, 1 \mathrm{H}, \mathrm{J}=7,87,1.75), 8.39(\mathrm{dt}, 1 \mathrm{H}$, $\mathrm{J}=9.10,1.21 \mathrm{~Hz}), 7,65(\mathrm{dd}, 1 \mathrm{H}, \mathrm{J}=4,67 \mathrm{~Hz}), 7,48(\mathrm{~m} 1 \mathrm{H}), 7.21(\mathrm{td}, 1 \mathrm{H}, \mathrm{J}=$ 6.84, $1.33 \mathrm{~Hz}), 4.50\left(\mathrm{q}, 2 \mathrm{H}, \mathrm{CH}_{2} \mathrm{~J}=7,16 \mathrm{~Hz}\right), 1.51\left(\mathrm{t}, 3 \mathrm{H}, \mathrm{CH}_{3}, \mathrm{~J}=7,13 \mathrm{~Hz}\right)$; ${ }^{13} \mathrm{C}$ NMR $\left(\mathrm{CDCl}_{3}\right): 14.1,61.2,106.1,117.9,121.4,126.8,127.1,128.2,128.4$, 130.6, 134.3, 150.5, 153.6, 163.4, 173.73, 177.6. HRMS (EI) $\mathrm{m} / \mathrm{z}$ calcd for $\mathrm{C}_{18} \mathrm{H}_{12} \mathrm{~N}_{2} \mathrm{O}_{4}: 320.0797$; found: 320.079331 .

12-acetylbenzo[f]pyrido[1,2-a]indole-6,11-dione (4): Red solid, mp 207.7-208.3 ${ }^{\circ} \mathrm{C}$; IR $\left(\mathrm{KBr}, \mathrm{v}_{\max } \mathrm{cm}^{-1}\right)$; $1666,1637,1493,1232,712 .{ }^{1} \mathrm{H}$ RMN $\left(\mathrm{CDCl}_{3}\right): 9.08(\mathrm{dt}, 1 \mathrm{H}, 2, \mathrm{~J}=7.02 \mathrm{~Hz}), 8.3(\mathrm{td}, 1 \mathrm{H}, 5, \mathrm{~J}=9.11 \mathrm{~Hz}), 8.2(\mathrm{~m}$, $2 \mathrm{H}, 14,17), 7,7$ (m, 2H, 15,16), 7,4 (t, 1H, 4, J= 5,6Hz), 7,2 (t, 1H, 5, J=5,6 $\mathrm{Hz}) ;{ }^{13} \mathrm{C}$ NMR $\left(\mathrm{CDCl}_{3}\right): 31.9,61.0,114.6,117.9,121.6,126.1,126.2,127.1$, 127.5, 128.0, 128.7, 133.1, 133.6, 139.3, 175.1, 181.9, 197.1. HRMS (EI) $m / z$ calcd for $\mathrm{C}_{18} \mathrm{H}_{11} \mathrm{NO}_{3} 289.0739$; found: 289.072456 .

6-acetylindolizino[2,3-g]quinoline-5,12-dione (5): Red solid, mp 250$251^{\circ} \mathrm{C}$; IR (KBr, $\left.\mathrm{v}_{\max } \mathrm{cm}^{-1}\right): 2962,1642,1491,1367,1312 ;{ }^{1} \mathrm{HRMN}$ (DMSO-d6): $9.69(\mathrm{~d}, 1 \mathrm{H}, 4, \mathrm{~J}=7.04 \mathrm{~Hz}), 8.95(\mathrm{~d}, 1 \mathrm{H}, 1, \mathrm{~J}=9.11 \mathrm{~Hz}), 8.51(\mathrm{dd}, 1 \mathrm{H}, \mathrm{J}=8.06$ $\mathrm{Hz}), 8.30(\mathrm{dd}, 1 \mathrm{H}, 2, \mathrm{~J}=7.52 \mathrm{~Hz}), 8.00(\mathrm{~m}, 2 \mathrm{H}, 3), 7.76(\mathrm{t}, 1 \mathrm{H}, \mathrm{J}=7,40 \mathrm{~Hz})$, 2.39 (s, 3H, $\mathrm{CH}_{3}$ ). HRMS (EI) $\mathrm{m} / z$ calcd for $\mathrm{C}_{17} \mathrm{H}_{10} \mathrm{~N}_{2} \mathrm{O}_{3} 290.06914$; found: 290.068753 .

6,11-dioxo-6,11-dihydrobenzo[f]pyrido[1,2-a]indole-12-carbonitrile (6): Red solid, mp 290.9-292.4 ${ }^{\circ} \mathrm{C}$; IR ( $\left.\mathrm{KBr}, \mathrm{v}_{\max } \mathrm{cm}^{-1}\right) ; 2221,1669,1642$, 1509, 1230; ${ }^{1} \mathrm{H} \mathrm{RMN}\left(\mathrm{CDCl}_{3}\right): 7.5(\mathrm{t}, 1 \mathrm{H}, 3, \mathrm{~J}=6.08 \mathrm{~Hz}), 7.8(\mathrm{~m}, 2 \mathrm{H}, 15,16)$, 7.9 (dt, 1H,4, J=8.99 Hz), $8.3(\mathrm{~m}, 3 \mathrm{H}, 14,17,5), 9.8(\mathrm{dd}, 1 \mathrm{H}, 2, \mathrm{~J}=6.1 \mathrm{~Hz})$; ${ }^{13} \mathrm{C}$ NMR $\left(\mathrm{CDCl}_{3}\right)$ : 94.5, 97.2, 120.4, 120.8, 121.5, 123.3, 126.0, 126.7, 132.1, 133.7, 133.9, 134.5, 135.1, 135.8, 150.0, 172.8, 180.0. HRMS (EI) $\mathrm{m} / z$ calcd for $\mathrm{C}_{17} \mathrm{H}_{8} \mathrm{~N}_{2} \mathrm{O}_{2}: 272.05858$; found: 272.058102 .

5,12-dioxo-5,12-dihydroindolizino[2,3-g]quinoline-6-carbonitrile (7): Orange solid, mp 290-292 ${ }^{\circ} \mathrm{C}$; IR $\left(\mathrm{KBr}, \mathrm{v}_{\max } \mathrm{cm}^{-1}\right) ; 2223,1657,1644,1511$, 1230; ${ }^{1} \mathrm{H}$ RMN(DMSO-d6): 9.51 (d, $1 \mathrm{H}, 4, \mathrm{~J}=6.92 \mathrm{~Hz}$ ), 8.91 (dd, $1 \mathrm{H}, 1, \mathrm{~J}=4.8$, $1.5 \mathrm{~Hz}), 8.48(\mathrm{dd}, 1 \mathrm{H}, \mathrm{J}=7.8,1.5 \mathrm{~Hz}), 7,91(\mathrm{~d}, 1 \mathrm{H}, \mathrm{J}=9.0 \mathrm{~Hz}), 7,78(\mathrm{dd}, 1 \mathrm{H}, \mathrm{J}=$ $7.8,4.8 \mathrm{~Hz}), 7,40(\mathrm{td}, 1 \mathrm{H}, \mathrm{J}=6.9,1,2 \mathrm{~Hz}), 7.28(\mathrm{td}, 1 \mathrm{H} \mathrm{J}=6.9,0.9 \mathrm{~Hz})$. HRMS (EI) $\mathrm{m} / z$ calcd for $\mathrm{C}_{17} \mathrm{H}_{9} \mathrm{~N}_{3} \mathrm{O}_{2}: 273.5383$; found: 273.531502 .

6,11-dioxo-6,11-dihydrobenzo[f]pyrido[1,2-a]indole-12-carboxylic acid (8): To a $100 \mathrm{~mL}$ round bottom flask it was added $0.5 \mathrm{~g}(2.2 \mathrm{mmol})$ of 2,3-dichloronaphthalene-1,4-dione, $2.2 \mathrm{mmol}$ of 2,2-dimethyl-1,3-dioxane4,6-dione and 22 eq. of pyridine in 30 of ethanol (solvent). The suspension was agitated by 6 hours; the purple precipitated was filtered and was washed with water gently. The yield was $95 \%$. Purple solid, mp 304.5-304. $9^{\circ} \mathrm{C}$; IR $(\mathrm{KBr}$, $\left.\mathrm{V}_{\mathrm{max}} \mathrm{cm}^{-1}\right): 3422,1645,1584,1233,715 .{ }^{1} \mathrm{H}$ RMN(DMSO-d6): 9.77 (d, 1H, 4, $\mathrm{J}=5.70 \mathrm{~Hz}), 9.45(\mathrm{t}, 1 \mathrm{H}, 1, \mathrm{~J}=7.82 \mathrm{~Hz}), 8.97(\mathrm{t}, 2 \mathrm{H}, 8,9, \mathrm{~J}=6.95 \mathrm{~Hz}), 8.87(\mathrm{~m}$, $2 \mathrm{H}, 15,16), 8.72(\mathrm{~m}, 2 \mathrm{H}, 2,3)$. HRMS (EI) $m / z$ calcd for $\mathrm{C}_{17} \mathrm{H}_{9} \mathrm{NO}_{4}: 291.05316$; found: 291.0528411

\section{Antiproliferative activity}

All human cell lines used in this work were purchased from the American Type Culture Collection (ATCC, Manasas, VA, USA). Normal lung fibroblasts (MRC-5), lung cancer cells (SK-MES-1) and bladder carcinoma cells (J82) were grown as monolayers in minimum essential Eagle medium (MEM) with Earles's salts, $2 \mathrm{mM} \mathrm{L}$-glutamine and $1.5 \mathrm{~g} / 1$ sodium bicarbonate, supplemented with $10 \%$ heat-inactivated fetal bovine serum (FBS), $100 \mathrm{IU} / \mathrm{ml}$ penicillin and $100 \mu \mathrm{g} / \mathrm{ml}$ streptomycin. Gastric epithelial cells AGS (CRL-1739) were grown as monolayers in Ham F-12 medium containing $1 \mathrm{mM} \mathrm{L}$-glutamine and $1.5 \mathrm{~g} / 1$ sodium bicarbonate, supplemented with $10 \%$ heat-inactivated FBS, $100 \mathrm{IU} / \mathrm{ml}$ penicillin and $100 \mu \mathrm{g} / \mathrm{ml}$ streptomycin. All cell lines were grown as monolayers in a humidified incubator with $5 \% \mathrm{CO}$ in air at $37^{\circ} \mathrm{C}$. For the antiproliferative assay, cells were plated at a density of $5 \times 10^{4}$ cells $/ \mathrm{mL}$ in 96 -well plates $(100$ $\mu \mathrm{L} /$ well). One day after seeding, cells were treated with medium containing the compounds at concentrations ranging from 0 up to $100 \mu \mathrm{M}$ during 3 days. The compounds were dissolved in DMSO ( $1 \%$ final concentration). Untreated 
cells (medium containing 1\% DMSO) were used as $100 \%$ viability controls. Etoposide ( $98 \%$ purity, Sigma-Aldrich, St. Louis, MO, USA) was used as the reference compound. Each concentration was tested in sextuplicate and experiments were repeated 2 times. Cell viability was determined by means of the MTT reduction assay at the end of the incubation with the products. The results were transformed to percentage of controls and the $\mathrm{IC}_{50}$ values were graphically obtained from the dose-response curves.

\section{ACKNOWLEDGMENT}

The authors are grateful to CONICYT, Bicentennial Project of Science and Technology Research Grant PSD-70, and FONDECYT (GRANT 1060592) for financial support.

\section{REFERENCES}

1. M. Tomasz, Chem. Biol. 2, 575, (1995).

2. K.A. Werbovetz, J. L. Bolton, Trust, M.A. Penning, T.M. Dryhurtst, G Monks, T.J. Chem. Res. Toxicol. 13, 135, (2000).

3. P.J. O’Brien, Chem. Biol. Interact. 80, 1, (1991).
4. D. Siegel, D. Ross, Free Radical Biol. Med. 29(3-4), 246, (2000).

5. M. F. Sartori, Chem. Rev. 63(3), 279-296, (1963).

6. L.M. Shi, T.G. Myers, Y. Fan, P.M. O’Connor, K.D. Paull, S.H. Friend, and J.N. Weinstein, Mol. Pharmacol., 53(2), 241-251. (1998).

7. G. Capranic, G. Zagotto, M. Palumbo, Current Medicinal Chemistry, 4, $335,(2004)$

8. M.H. Moore, W.H. Hunter, B.L. D`estaintot, O.J. Kenard, Mol. Biol. 206, 693, (1989)

9. Y. Chen, L. Hu, Medicinal Research Reviews, 29(1), 29, (2009).

10. C.G. Xing, E.B. Skibo, Abs Papers Am. Chem. Soc. 220, U567-U567, (2000).

11. C. Solorio-Alvarado, E. Peña-Cabrera, J. García-Soto, J. López-Godínez, F. González, A. Álvarez-Hernández, ARKIVOC, (ii), 239, (2009). 